\title{
IMPLEMENTASI PERDA KOTA PADANG NOMOR 2 TAHUN 2013 TENTANG PENANGGULANGAN KEMISKINAN DAN PENINGKATAN KESEJAHTERAAN OLEH DINAS SOSIAL KOTA PADANG
}

\author{
Yesi Ermaini Simamora \\ Jurusan Administrasi Publik, Fakultas Ilmu Sosial, Universitas Negeri Padang \\ yesiermainis@gmail.com

\section{Afriva Khaidir} \\ Jurusan Administrasi Publik, Fakultas Ilmu Sosial, Universitas Negeri Padang \\ af.khaidir@gmail.com
}

\begin{abstract}
Poverty alleviation is a policy of the central and regional government programs that are carried out systematically, planned and synergized with the business community and the community to reduce the number of poor people in order to improve the welfare of the community. This study aims to determine the Implementation of Regional Regulation Number 2 of 2013 concerning Poverty Reduction and Welfare Improvement by the Social Service in Koto Tangah Subdistrict, Padang City. This research is motivated by the implementation of poverty alleviation is not right on target. There are still many poor people, especially in the District of Koto Tangah and lack of awareness of people who claim to be poor. This research is descriptive with a qualitative approach. Informants were determined by purposive sampling and random. Data is collected through interviews, observation and documentation. The results of this study showed that the implementation of poverty reduction program policies that have not been effective.
\end{abstract}

Keywords: Implementation, Policy, Poverty Reduction Program.

\section{Pendahuluan}

Kemiskinan merupakan problematika kemanusian negara-negara berkembang di dunia. Kemiskinan seringkali dipahami dengan rendahnya tingkat kesejahteraan semata. Padahal kemiskinan merupakan gejala yang bersifat kompleks dan multidimensi. Salah satu negara yang masih dibelit kemiskinan adalah negara Indonesia. Menurut Soekanto (2010) Kemiskinan adalah suatu keadaan dimana seseorang tidak sanggup memelihara dirinya sendiri sesuai dengan ukuran kehidupan kelompoknya, dan juga tidak mampu memanfaatkan tenaga mental maupun fisiknya dalam kelompok tersebut. Kemiskinan adalah masalah yang bersifat multi dimensi dan multi sektor dengan beragam karakteristik yang harus segera diatasi karena menyangkjut harkat dan martabat manusia, maka penanggulangan kemiskinan perlu keterpaduan program dan melibatkan partisipasi masyarakat. Penanggulangan dan pengentasan kemiskinan sebagai tindakan pemerintah yang ditunggu masyarakat untuk mengurangi kemiskinan yang kian merebak. Seperti kurangnya pangan, kawasan perkampungan kumuh, 


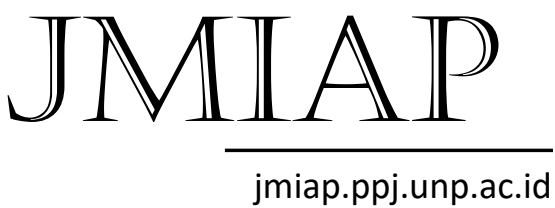

jmiap.ppj.unp.ac.id
Email : jianfis.unp@gmail.com

Vol. 1 No. 1 Tahun 2018 pendidikan rendah dan banyaknya pengangguran dan/atau gelandangan.

Penanggulangan dan pengentasan kemiskinan sebagai tindakan pemerintah yang ditunggu masyarakat untuk mengurangi kemiskinan yang kian merebak. Seperti kurangnya pangan, kawasan perkampungan kumuh, pendidikan rendah dan banyaknya pengangguran dan/atau gelandangan. Perkembangan kemiskinan di Indonesia masih belum teratasi secara maksimal, hal ini dapat dilihat dari jumlah penduduk miskin di Indonesia dari tahun 19982017, kecuali pada tahun 2006, September 2013, dan Maret 2015 tingkat kemiskinan di Indonesia mengalami penurunan. Saat ini jumlah penduduk miskin di Tahun 2017 mencapai 27,77 juta orang (Berita resmi statistik No. 05/01/Th. XX, 3 Januari 2017).

Penanggulangan kemiskinan dibuat dan dilaksanakan oleh pemerintah yang bertujuan untuk mewujudkan kesejahteraan rakyat. Pemerintah terdiri dari pemerintah pusat dan pemerintah daerah baik provinsi maupun kabupaten/kota. Kota Padang merupakan Ibukota Provinsi Sumatera Barat, dengan kepala pemerintahannya seorang Walikota. Selain itu Walikota juga merupakan unsur penyelenggaraan pemerintahan daerah yang dilaksanakan bersama dengan perangkat daerah.

Kota Padang merupakan salah satu kota besar yang berada di pesisir barat Sumatera. Jumlah kecamatan yang ada di Kota Padang sebanyak 11 kecamatan yaitu Bungus Teluk Kabung, Lubuk Kilangan, Lubuk Begalung, Padang Selatan, Padang Timur, Padang Utara, Padang Barat, Nanggalo, Kuranji, Pauh dan Koto Tangah. Untuk dapat melihat jumlah kemiskinan di Kota Padang dapat dilihat berdasarkan keluarga sejahtera. Keluarga Sejahtera adalah keluarga yang dibentuk berdasarkan atas perkawinan yang sah, mampu memenuhi kebutuhan hidup spiritual dan materiil yang layak, bertaqwa kepada Tuhan Yang Maha Esa, memiliki hubungan yang serasi, selaras dan seimbang antar anggota dan antar keluarga dengan masyarakat dan lingkungan (Undang-Undang Republik Indonesia Nomor 10 tahun 1992).

Menurut BKKBN (Badan

Kependudukan dan Keluarga Berencana Nasional) Tingkat Keluarga sejahtera dapat dikelompokkan menjadi 5 tingkatan yaitu Keluarga Pra Sejahtera, Keluarga Sejahtera I, Keluarga Sejahtera II, dan Keluarga Sejahtera III. Kecamatan yang memiliki tingkat keluarga pra sejahtera tertinggi adalah kecamatan Koto Tangah sebanyak 635 KK, dan yang terendah berada di kecamatan Padang Utara sebanyak 61 KK. Kecamatan yang memiliki tingkat keluarga sejahtera I tertinggi adalah kecamatan Koto Tangah sebanyak 2703 KK, dan yang terendah berada di kecamatan Padang Utara sebanyak 123 KK. Kecamatan yang memiliki tingkat keluarga sejahtera II tertinggi adalah kecamatan Koto Tangah sebanyak 8255 KK, dan yang terendah berada di kecamatan Padang Utara sebanyak 905 KK. Sementara itu kecamatan yang memiliki tingkat keluarga sejahtera III tertinggi adalah kecamatan Koto Tangah sebanyak $975 \mathrm{KK}$, dan yang terendah berada di kecamatan Kuranji sebanyak 105 KK. jumlah kemiskinan yang paling banyak terdapat di kecamatan Koto Tangah.

Kecamatan Koto Tangah dipilih menjadi subjek penelitian karena adanya kesesuaian minat peneliti terhadap masalah yang ada di kecamatan Koto 


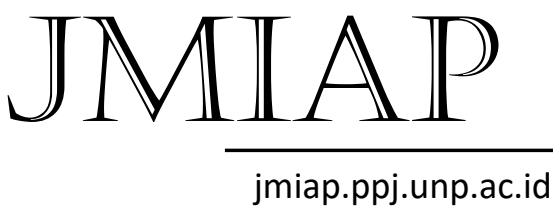

jmiap.ppj.unp.ac.id
Email : jianfis.unp@gmail.com

Vol. 1 No. 1 Tahun 2018
Tangah, dengan konsentrasi penelitian pada penanggulangan kemiskinan. Pemerintah dalam melakukan penanggulangan kemiskinan membutuhkan sinergitas melalui koordinasi, sinkronisasi dan integrasi instansi pemerintah.

Pemerintah Kota Padang mempunyai aturan hukum tersendiri untuk mengatasi kemiskinan yaitu Peraturan Daerah Nomor 2 tahun 2013 tentang Penanggulangan Kemiskinan dan Peningkatan Kesejahteraan. Dengan adanya perda tersebut diharapkan program penanggulangan kemiskinan Kota Padang dapat terarah dan terealisasi dengan tepat, maka pemerintah membentuk Tim Koordinasi Penanggulangan Kemiskinan (TKPK) dengan mengeluarkan Surat Keputusan (SK) Walikota Padang Nomor 146 Tahun 2018 sebagai unit pengaduan kegiatan pemberdayaan masyarakat program penanggulangan kemiskinan yang berada di bawah dan bertanggung jawab kepada Walikota. TKPK mempunyai tugas melakukan langkah-langkah konkrit untuk mempercepat pengurangan jumlah penduduk miskin melalui koordinasi dan sinkronisasi penyusunan dan pelaksanaan penajaman kebijakan penanggulangan kemiskinan.

Pembentukan Tim Koordinasi Penanggulangan Kemiskinan (TKPK) di tingkat Provinsi dan Kabupaten/Kota didasari dari adanya Peraturan Presiden Nomor 15 Tahun 2010 Tentang Percepatan Penanggulangan Kemiskinan dan bersangkutan. Struktur kelembagaan dan mekanisme kemuadian diatur dalam Peraturan Menteri Dalam Negeri (Permendagri) Nomor 42 Tahun 2010 tentang kerja Tim Koordinasi Penanggulangan Kemiskinan Provinsi dan Kabupaten/ Kota. Tim ini merupakan tim lintas sektor dan lintas pemangkupemangku kepentingan di tingkat Provinsi, Kabupaten/Kota untuk melakukan percepatan penanggulangan kemiskinan di masing-masing tingkat daerah yang diharapkan mampu mendorong kerjasama dan sinergitas antar instansi pemerintah sehingga penangulangan kemiskinan dapat berjalan secara efisien dan efektif.

Program penanggulangan kemiskinan merupakan kegiatan yang dilakukan secara terpadu dan diharapkan sinergitas antara pemerintah kota, dunia usaha, perguruan tinggi, dan masyarakat untuk meningkatkan kesejahteraan warga miskin melalui bantuan sosial, pemberdayaan masyarakat, serta pemberdayaan usaha ekonomi mikro. Pemerintah melalui Peraturan Daerah Kota Padang Nomor 2 Tahun 2013 tentang Penanggulangan Kemiskinan dan Peningkatan Kesejahteraan telah menetapkan instrumen penanggulangan kemiskinan yang terdiri dari tiga kelompok program utama, yaitu: (1) Kelompok program bantuan sosial terpadu berbasis keluarga, (2) Kelompok program penanggulangan kemiskinan berbasis pemberdayaan masyarakat, (3) Kelompok program penanggulangan Kemiskinan Berbasis Pemberdayaan Usaha Ekonomi Mikro dan Kecil, (4) Kelompok program lainnya.

Pelaksanaan Peraturan Daerah Kota Padang Nomor 2 Tahun 2013 Tentang Penanggulangan Kemiskinan dan Peningkatan Kesejahteraan, salah satunya melibatkan Dinas Sosial. Dinas sosial merupakan salah satu dari dua belas (12) tim koordinasi penanggulangan kemiskinan (TKPK) yang aktif di Kota Padang. Program penanggulangan kemiskinan yang dilakukan oleh dinas sosial kota padang 


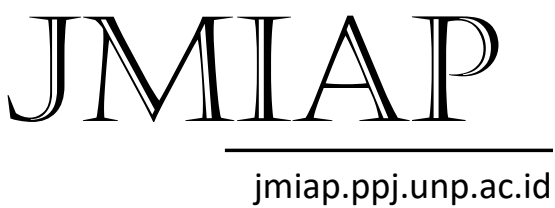

jmiap.ppj.unp.ac.id
Email : jianfis.unp@gmail.com

Vol. 1 No. 1 Tahun 2018 yaitu program bantuan sosial terpadu berbasis keluarga. Salah satu program bantuan sosial terpadu berbasis keluarga yang yaitu Program Keluarga Harapan (PKH) dan Beras Sejahtera (Rastra).

Program-program yang sudah diberikan oleh Dinas Sosial Kota Padang akan terlaksanan dengan baik jika diiringi dengan kerja nyata dari pemerintah itu sendiri. Kesungguhan Dinas Sosial dalam upaya peningkatan taraf hidup masyarakatnya dapat dilihat dari suksesnya pelaksanaan program tersebut. Untuk itu, diperlukan secara sistematis, terencana dan bersinergi guna menanggulangi kemiskinan di Kota Padang.

Dengan melihat permasalahan di atas, maka peneliti tertarik untuk melakukan penelitian mengenai Implementasi Perda Kota Padang Nomor 2 tahun 2013 tentang Penanggulangan Kemiskinan dan Peningkatan Kesejahteraan oleh Dinas Sosial di Kecamatan Koto Tangah tersebut diatas maka dapat ditentukan rumusan masalah penelitian sebagai berikut :

1. Bagaimana Implementasi Perda Kota Padang Nomor 2 Tahun 2013 tentang Penanggulangan Kemiskinan dan Peningkatan Kesejahteraan oleh Dinas Sosial di Kecamatan Koto Tangah?

2. Apa saja faktor-faktor yang mempengaruhi dalam mengimplementasikan Perda Kota Padang Nomor 2 Tahun 2013 tentang Penanggulangan Kemiskinan dan Peningkatan Kesejahteraan oleh Dinas Sosial di Kecamatan Koto Tangah?

\section{Tinjauan Kepustakaan Implementasi kebijakan}

Joko Widodo (dalam Herabudin, 2016) menyimpulkan bahwa implementasi merupakan proses yang melibatkan sejumlah sumber yang termasuk manusia, dana, dan kemampuan organisasional yang dilakukan oleh pemerintah ataupun swasta ( individu/kelompok). Sahya (2014) bahwa implementasi merupakan suatu kegiatan atau usaha yang dilakukan oleh pelaksana kebijakan dengan harapan akan memperoleh suatu hasil yang sesuai dengan tujuan atau sasaran dari suatu kebijakan.

Faktor-faktor yang memnpengaruhi implementansi kebijakan yang digunakan model George $\mathrm{C}$. Edward III, yaitu

a) Komunikasi, yaitu menunjuk bahwa setiap kebijakan akan dapat dilakukan dengan baik jika terjadi komunikasi efektif antara pelaksana program (kebijakan) dengan para kelompok sasaran (target group). Tujuan dan sasaran dari program/kebijakan dapat disosialisasikan secara baik sehingga dapat menghindari adanya distorsi atas kebijakan dan program. Ini menjadi penting karena semakin tinggi pengetahuan kelompok sasaran atas program maka akan mengurangi tingkat penolakan dan kekeliruan dalam mengaplikasikan program dan kebijakan dalam ranah yang sesungguhnya.

b) Sumber daya, yaitu menunjuk setiap kebijakan yang harus didukung oleh sumber daya yang memadai, baik sumber daya manusia maupun sumber daya finansial. Sumber daya manusia adalah kecukupan baik kualitas maupun kuantitas implementor yang dapat melingkupi seluruh kelompok sasaran. Sumber daya finansial adalah kecukupan modal investasi atas sebuah program/kebijakan. Keduanya harus 
diperhatikan dalam implementasi program/kebijakan pemerintah. Sebab tanpa kehandalan implementor, kebijakan menjadi kurang enerjik dan berjalan lambat dan seadanya. Sedangkan, sumber daya finansial menjamin keberlangsungan program/kebijakan. Tanpa ada dukungan finansial yang memadai, program tak dapat berjalan efektifdan cepat dalam mencapai tujuan dan sasaran.

c) Disposisi, yaitu menunjuk karakteristik yang menempel erat kepada implementor kebijakan/program. Karakter yang penting dimiliki oleh implementor adalah kejujuran, komitmen dan demokratis. Implementor yang memiliki komitmen tinggi dan jujur akan senantiasa bertahan diantara hambatan yang ditemui dalam program/kebijakan. Kejujuran mengarahkan implementor untuk tetap berada dalam arah program yang telah digariskan dalam guidiline program. Komitmen dan kejujurannya membawanya semakin antusias dalam melaksanakan tahaptahap program secara konsisten. Sikap yang demokratis akan meningkatkan kesan baik implementor dan kebijakan dihadapan anggota kelompok sasaran. Sikap ini akan menurunkan resistensidari masyarakat dan menumbuhkan rasa percaya dan kepedulian kelompok sasaran terhadap implementor dan program/kebijakan.

d) Struktur Birokrasi, menunjuk bahwa struktur birokrasi menjadi penting dalam implementasi kebijakan. Aspek struktur birokrasi ini mencakup dua hal penting pertama adalah mekanisme, dan struktur organisasi pelaksana sendiri. Mekanisme implementasi program biasanya sudah ditetapkan melalui standar operating procedur (SOP) yang dicantumkan dalam guideline program/kebijkan. SOP yang baik mencantumkan kerangka kerja yang jelas, sistematis, tidak berbelit dan mudah dipahami oleh siapapun karena akan menjadi acuan dalam bekerjanya implementor. Sedangkan struktur organisasi pelaksana pun sejauh mungkin menghindari hal yang berbelit, panjang dan kompleks. Struktur organinasi pelaksana harus dapat menjamin adanya pengambilan keputusan atas kejadian luar biasa dalam program secara cepat. Dan hal ini hanya dapat lahir jika struktur didesain secara ringkas dan fleksibel menghindari "virus weberian" yang kaku, terlalu hirarkhis dan birokratis.

\section{Kemiskinan}

Menurut Elly dan Usman (2011) kemiskinan merupakan masalah multidimensi dan lintas sektor yang dipengaruhi oleh berbagai fakor yang saling berkaitan, antara lain: tingkat pendapatan, kesehatan, pendidikan, akses terhadap barang dan jasa, geografis, gender, dan kondisi lingkungan.Kemiskinan itu sendiri menurut Ambar dalam Sungkowon (2017:6), ditandai oleh kondisi masyarakat yang serba terbatas, baik dalam aksebilitas pada faktor produksi, peluang atau kesempatan berusaha, pendidikan, serta fasilitas hidup lainnya sehingga dalam setiap aktivitas maupun usaha menjadi sangat terbatas. Menurut Salim dalam Yozi (2010) memberikan ciri-ciri kemiskinan sebagai berikut: 
1) Mereka yang tidak mempunyai faktor produksi sendiri (seperti tanah, modal dan keterampilan)

2) Tidak memiliki kemungkinan untuk memiliki asset produksi dengan kekuatan sendiri

3) Rata-rata pendidikan mereka rendah

4) Sebagian besar mereka tinggal di pedesaan dan bekerja sebagai buruh tani. yang tinggal di kota kebanyakan mereka yang berusia muda dan tidak memiliki keterampilan dan pendidikannya rendah.

Bappenas dalam Agus (2014) telah menetapkan lima strategi nasional penanggulangan kemiskinan (SNPK), yaitu:

1) Perluasan kesempatan, yaitu untuk menciptakan kondisi dan lingkungan ekonomi, politik, dan sosial yang memungkinkan masyarakat miskin, baik laki-laki maupun perempuan dapat memperoleh kesempatan seluas-luasnya dalam pemenuhan hak-hak dasar dan peningkatan taraf hidup secara berkelanjutan.

2) Pemberdayaan kelembagaan masyarakat, yaitu untuk memperkuat pasrtisipasi masyarakat miskin, baik laki-laki maupun perempuan dalam pengambilan keputusan kebijakan publik yang menjamin penghormatan, perlindungan dan pemenuhan hak-hak dasar.

3) Peningkatan kapasitas, yaitu untuk mengembangkan kemampuan dasar dan kemampuan berusaha miskin, baik laki-laki maupun perempuan agar dapat memanfaatkan perkembangan lingkungan.

4) Perlindungan sosial, yaitu untuk memberikan perlindungan dan rasa aman bagi kelompok yang rentan (perempuan kepala rumah tangga, fakir miskin, orang jompo, anak

terlantar, kemampuan berbeda/penyandang cacat) dan masyarakat miskin baru, baik lakilaki maupun perempuan disebabkan oleh: bencana alam, berdampak negatif krisis ekonomi dan konflik sosial).

5) Penataan kemitraan global, yaitu untuk mengembangkan dan menataulang hubungan dan kerjasama internasional guna mendukung pelaksanaan keempat strategi tersebut.

\section{Keluarga Sejahtera}

Keluarga Sejahtera adalah keluarga yang dibentuk berdasarkan atas perkawinan yang sah, mampu memenuhi kebutuhan hidup spiritual dan materiil yang layak, bertaqwa kepada Tuhan Yang Maha Esa, memiliki hubungan yang serasi, selaras dan seimbang antar anggota dan antar keluarga dengan masyarakat dan lingkungan (Undang-Undang Republik Indonesia Nomor 10 tahun 1992).

Tingkat Keluarga sejahtera di kelompokkan menjadi 5 tingkatan menurut BKKBN (Badan Kependudukan dan Keluarga Berencana Nasional) yaitu Keluarga Pra Sejahtera yaitu keluargakeluarga yang belum dapat memenuhi kebutuhan dasarnya seperti kebutuhan agama, pangan, sandang, dan kesehatan., Keluarga Sejahtera I yaitu keluargakeluarga yang telah dapat memenuhi kebutuhan dasar, tetapi belum dapat memenuhi kebutuhan sosial psikologisnya, Keluarga Sejahtera II yaitu keluarga-keluarga yang dapat memenuhi seluruh kebutuhan dasar dan kebutuhan sosial psikologisnya, tetapi belum dapat memenuhi kebutuhan perkembangannya seperti menabung dan memperoleh informasi, dan Keluarga Sejahtera III keluarga yang dapat 


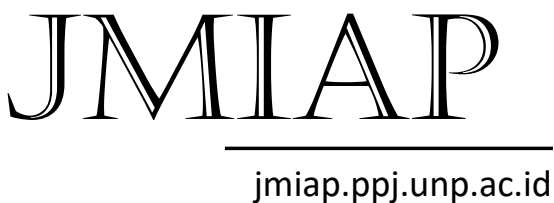

jmiap.ppj.unp.ac.id
Email : jianfis.unp@gmail.com

Vol. 1 No. 1 Tahun 2018 memenuhi kebutuhan dasar, kebutuhan sosial psikologis, dan kebutuhan pengembangan, namun belum dapat memberikan sumbangan maksimal terhadap masyarakat.

Adapun Indikator-indikator dari tingkat keluarga sejahtera menurut BKKBN (Badan Kependudukan dan Keluarga Berencana Nasional) yaitu

1) Indikator Pra Sejahtera adalah keluarga yang tidak dapat memenuhi salah satu 6 ( enam dari indikator keluarga sejahtera I)

2) Indikator Keluarga Sejahtera I adalah:

a) Pada umumnya anggota keluarga makan dua kali sehari atau lebih.

b) Anggota keluarga memiliki pakaian yang berbeda untuk di rumah, bekerja/sekolah dan bepergian.

c) Rumah yang ditempati keluarga mempunyai atap, lantai dan dinding yang baik.

d) Bila ada anggota keluarga sakit dibawa ke sarana kesehatan.

e) Bila pasangan usia subur ingin ber $\mathrm{KB}$ pergi ke sarana pelayanan kontrasepsi.

f) Semua anak umur 7-15 tahun dalam keluarga bersekolah

3) Indikator Keluarga Sejahtera II adalah:

a) Pada umumnya anggota keluarga melaksanakan ibadah sesuai dengan agama dan kepercayaan masing-masing.

b) Paling kurang sekali seminggu seluruh anggota keluarga makan daging/ikan/telur.

c) Seluruh anggota keluarga memperoleh paling kurang satu stel pakaian baru dalam setahun.

d) Luas lantai rumah paling kurang 8 $\mathrm{m} 2$ untuk setiap penghuni rumah. e) Tiga bulan terakhir keluarga dalam keadaan sehat sehingga dapat melaksanakan tugas/fungsi masing-masing.

f) Ada seorang atau lebih anggota keluarga yang bekerja untuk memperoleh penghasilan.

g) Seluruh anggota keluarga umur 10 - 60 tahun bisa baca tulisan latin.

h) Pasangan usia subur dengan anak dua atau lebih menggunakan alat/obat kontrasepsi.

4) Indikator Keluarga sejahtera III yaitu:

a) Keluarga berupaya meningkatkan pengetahuan agama.

b) Sebagian penghasilan keluarga ditabung dalam bentuk uang atau barang.Kebiasaan keluarga makan bersama paling kurang seminggu sekali dimanfaatkan untuk berkomunikasi.

c) Keluarga ikut dalam kegiatan masyarakat di lingkungan tempat tinggal.

d) Keluarga memperoleh informasi dari surat kabar/majalah/radio/tv/internet.

\section{Metode Penelitian}

Jenis penelitian yang dilakukan adalah penelitian kualitatif dengan menggunakan metode deskriptif. Penelitian dilakukan di Kecamatan Koto Tangah, Kantor Walikota Padang, Kantor BAPPEDA Kota Padang, Kantor Dinas Sosial Kota Padang, Kantor BPKAD Kota Padang, Kantor Camat Koto Tangah, Kantor Lurah Dadok Tunggul Hitam, Kantor Lurah Pasie Nan Tigo, dan masyarakat yang menerima dan tidak menerima bantuan sosial di Kecamatan Koto Tangah. Informan dalam penelitian ini ditentukan dengan teknik purposive sampling dan random. 


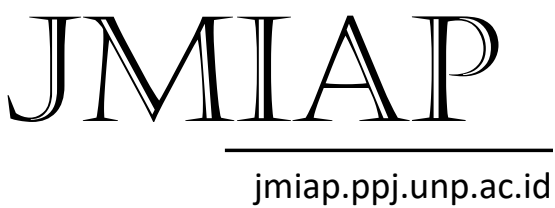

jmiap.ppj.unp.ac.id
Email : jianfis.unp@gmail.com

Vol. 1 No. 1 Tahun 2018
Teknik pengumpulan data dalam penelitian ini yaitu wawancara, observasi dan dokumentasi. Tehnik yang digunakan untuk menguji keabsahan data menggunakan tehnik triangulasi sumber. Adapun analisis data dilihat dari pengumpulan data, reduksi data, penyajian data dan penarikan kesimpulan. Dari tehnik triangulasi itu untuk memeriksa keabsahan data dari data hasil wawancara, observasi dan dokumentasi untuk dilihat kecocokan data yang dilapangan.

\section{Hasil Penelitian dan Pembahasan}

\section{Hasil Penelitian}

Dalam Peraturan Daerah Nomor 2 Tahun 2013 tentang Penanggulangan Kemiskinan dan Peningkatan Kesejahteraan memuat beberapa program diantaranya:

a) Kelompok program berbasis keluarga sebagaimana dimaksud dalam pasal 24 ayat 2 huruf a, melaksanakan sebagian tugas TKPK kota, kecamatan dan kelurahan dalam melakukan koordinasi penanggulangan kemiskinan dibidang bantuan sosial terpadu berbasis keluarga

b) Kelompok kemiskinan penanggulangan berbasis pememberdayaan masyarakat sebagai mana dimaksud dalam pasal 24 ayat 2 huruf $b$, melaksanakan sebagian tugas TKPK kota, kecamatan dan keluarahan dalam melakukan koordinasi penanggulangan kemiskinan dibidang pemberdayaan masyarakat. c) Kelompok program penanggulangan kemiskinan berbasis pemberdayaan usaha ekonomi mikro dan kecil sebagaimana dimaksud dalam pasal 24 ayat 2 huruf c, melaksanakan sebagian tugas TKPK kota, kecamatan dan kelurahan dalam melakukan penanggulangan kemiskinan dibidang pemberdayaan usaha mikro dan kecil.

Dari beberapa program TKPK kota padang diatas penulis meneliti tentang program bantuan sosial terpadu berbasis keluarga. Salah satu pelaksana program tersebut adalah dinas sosial kota padang. Program bantuan sosial terpadu berbasis keluarga terbagi menjadi dua bagian program bantuan sosial yaitu Program Keluarga Harapan (PKH) dan Program Beras Sejahtera (Rastra). Program Keluarga Harapan (PKH) adalah program pemberian uang tunai kepada rumah tangga sangat miskin (RTSM) berdasarkan persyaratan dan ketentuan yang telah ditetapkan dengan melaksanakan kewajibannya. Program Keluarga Harapan (PKH) dimulai pada tahun 2007 dengan uji coba di beberapa provinsi, yang kemudian diterapkan pada tahun 2011 di 25 provinsi. Sumatera Barat menjadi salah satu provinsi yang tercatat menjadi penerima Program keluarga harapan $(\mathrm{PKH})$. Setiap masyrakat penerima PKH juga termasuk dalam penerima program beras sejahtera (Rastra). Kedua program ini dibentuk oleh Dinas Sosial untuk tujuan mengurangi angka kemiskinan yang tinggi di kota Padang. Dibawah ini dapat dilihat angka kemiskinan di Kota Padang menurut kecamatan dan klarifikasi. 


\section{Tabel 2. Jumlah Keluarga Sejahtera Menurut Kecamatan dan Klasifikasi Kota Padang 2017}

\begin{tabular}{|c|c|c|c|c|c|c|}
\hline \multirow[t]{2}{*}{ No } & \multirow{2}{*}{ Kecamatan } & Pra & \multicolumn{3}{|c|}{ Keluarga sejahtera } & \multirow{2}{*}{ Jumlah } \\
\hline & & sejahtera & I & II & III & \\
\hline 1 & Bungus Teluk Kabung & 110 & 381 & 1993 & 318 & 2802 \\
\hline 2 & Lubuk Kilangan & 154 & 1398 & 7401 & 351 & 9304 \\
\hline 3 & Lubuk Begalung & 213 & 821 & 3043 & 685 & 4762 \\
\hline 4 & Padang Selatan & 86 & 756 & 3386 & 729 & 4957 \\
\hline 5 & Padang Timur & 98 & 1758 & 9113 & 582 & 11551 \\
\hline 6 & Padang Barat & 78 & 504 & 2214 & 267 & 3063 \\
\hline 7 & Padang Utara & 61 & 123 & 905 & 235 & 1324 \\
\hline 8 & Nanggalo & 85 & 213 & 2019 & 410 & 2727 \\
\hline 9 & Kuranji & 250 & 1425 & 4784 & 105 & 6564 \\
\hline 10 & Pauh & 76 & 1508 & 8236 & 256 & 10076 \\
\hline 11 & Koto Tangah & 635 & 2703 & 8255 & 975 & 12568 \\
\hline \multicolumn{2}{|c|}{ Jumlah Total } & 1846 & 11590 & 51349 & 4913 & 69698 \\
\hline
\end{tabular}

Melihat kondisi kemiskinan tersebut, program $\mathrm{PKH}$ dan program Rastra di Kota Padang diberikan anggaran kurang lebih sebesar Rp 1,6 milyar. Jumlah uang yang di terima pada kartu keluarga sejahtera sebesar Rp. 200.000 setiap bulannya dan jumlah beras yang di dapat penerima manfaat rastra sebesar $15 / \mathrm{kg}$ perbulannya. Anggaran tersebut diberikan dalam bentuk bantuan sosial, yang disesuaikan dengan klarifikasi keadaan masyarakat. Pembayaran tersebut dibagi dalam empat tahap dan dibayarkan sekali tiga bulan. Jumlah penerima PKH di Kota Padang dapat dilihat pada tabel dibawah ini:

Tabel 3. Jumlah Penerima Bantuan Sosial Menurut Kecamatan Di Kota Padang Tahun 2017

\begin{tabular}{lc}
\hline \multicolumn{1}{c}{ Kecamatan } & Penerima \\
\hline Bungus Teluk Kabung & 305 \\
Koto Tangah & 958 \\
Kuranji & 902 \\
Lubuk Begalung & 618 \\
Lubuk Kilangan & 221 \\
Nanggalo & 294 \\
Padang Barat & 489 \\
Padang Selatan & 718 \\
Padang Timur & 564 \\
Padang Utara & 274 \\
Pauh & 387 \\
\hline
\end{tabular}

Yesi Ermaini Simamora, Afriva Khaidir |36 
Kecamatan Koto Tangah merupakan kecamatan yang memiliki jumlah penduduk miskin yang terbanyak di antara 11 kecamatan di Kota Padang.
Tujuan utama dari kebijakan ini adalah untuk menanggulangi permasalahan kemiskinan di Kota Padang khususnya di Kecamatan Koto Tangah.

Tabel 4. Jumlah Penerima Bantuan Sosial (KIP, KIS dan KKS) di Kecamatan Koto Tangah Kota Padang Tahun 2017

\begin{tabular}{lcccccc}
\hline \multicolumn{1}{c}{ Kelurahan } & KIP & KIS & KKS & \multicolumn{3}{c}{ Penerima (KK) } \\
\cline { 5 - 7 } & (Jiwa) & $($ Jiwa) & $($ KK) & 1 & $\mathbf{2}$ & $\mathbf{3}$ \\
\hline Dadok Tunggul Hitam & 255 & 430 & 95 & 47 & 30 & 18 \\
Air Pacah & 156 & 267 & 70 & 30 & 22 & 18 \\
Lubuk Minturun & 205 & 355 & 87 & 47 & 30 & 10 \\
Bungo Pasang & 150 & 232 & 67 & 31 & 22 & 15 \\
Parupuak Tabing & 233 & 458 & 105 & 63 & 32 & 10 \\
Batang Kabung & 135 & 254 & 65 & 42 & 11 & 12 \\
Lubuk Buaya & 120 & 305 & 58 & 27 & 21 & 10 \\
Padang Sarai & 200 & 210 & 68 & 34 & 21 & 13 \\
Koto panjang & 110 & 350 & 73 & 43 & 17 & 13 \\
Pasie Nan Tigo & 201 & 380 & 90 & 47 & 30 & 13 \\
Koto Pulai & 95 & 203 & 45 & 18 & 17 & 10 \\
Balai gadang & 200 & 231 & 70 & 34 & 25 & 11 \\
Batipuh panjang & 145 & 230 & 65 & 42 & 13 & 10 \\
\hline
\end{tabular}

\section{Sumber: Kantor Kecamatan Koto Tangah}

Dari tabel diatas dapat dilihat bahwa jumlah penerima bantuan sosial (KIP, KIS dan KKS) di kecamatan Koto Tangah Kota Padang tahun 2017, untuk penerima kartu indonesia pintar terbanyak adalah kelurahan dadok tunggul hitam yaitu sebanyak 255 jiwa.
Untuk jumlah masyarakat penerima kartu indonesia sehat tertinggi berada pada kelurahan parupuk tabing yaitu 458 jiwa, sedangkan untuk jumlah penerima kartu keluarga sejahtera yang tertinggi berada pada kelurahan parupuk tabing yaitu 105 jiwa.

Tabel 5. Rekapitulasi Jumlah Penerima Bantuan Sosial di Kecamatan Koto Tangah Kota Padang Tahun 2017

\begin{tabular}{lccc}
\hline \multicolumn{1}{c}{ Kelurahan } & Data Lama & Data Terbaru & $+/-$ \\
\hline Dadok Tunggul Hitam & 74 & 95 & +21 \\
Air Pacah & 56 & 70 & +26 \\
Lubuk Minturun & 78 & 87 & +9 \\
Bungo Pasang & 56 & 67 & +11 \\
Parupuk Tabing & 85 & 105 & +20 \\
Batang Kabung Ganting & 70 & 65 & -5 \\
\hline
\end{tabular}




\begin{tabular}{lccc}
\hline Lubuk Buaya & 76 & 58 & -18 \\
Padang Sarai & 80 & 68 & -12 \\
Koto Panjang Ikur Koto & 85 & 73 & -12 \\
Pasie Nan Tigo & 62 & 90 & +28 \\
Koto Pulai & 51 & 45 & -6 \\
Balai Gadang & 85 & 70 & -15 \\
Batipuh Panjang & 72 & 65 & -7 \\
Jumlah & 930 & 958 & 190 \\
\hline
\end{tabular}

Sumber: Kantor Kecamatan Koto Tangah

Di Kecamatan Kota Padang penerima bantuan sosial pada tahun ke tahun yang mengalami peningkatan penerima, dimana setiap tahun penerima bertambah. Dapat dilihat dari rekapitulasi jumlah penerima bantuan sosial di Kecamatan Koto Tangah yaitu jumlah tahun sebelumnya penerima bantuan sosial sekitar 930 sedangkan pada tahun berikutnya mengalami peningktan sebesar 958 penerima banttuan sosial. Kelurahan yang mengalami peningkatan penerima bantuan sosial salah satunya yaitu Bungo Pasang, Dadok Tunggul Hitam dan Pasie Nan Tigo.

Adapun beberapa faktor-faktor yang mempengaruhi implementasi setelah hasil penelitian yang terjadi saat pelaksanaan program/kebijakan:

a) Dalam program penanggulangan kemiskinan yang dilaksanakan di kecamatan Koto Tangah yaitu masyarakat yang telah menerima bantuan sosial yang seharusnya mengalami perubahan perekonomian namun masih mengaku berada di zona kemiskinan sehingga keberhasilan dalam program penanggulangan kemiskinan tidak berdampak mengurangi kemiskinan masyarakat kecamatan koto tangah.

b) Dari tahun ke tahun pelaksanaan program penanggulangan kemiskinan dilaksanakan dengan sistem top down yaitu keputusan masih berada dipusat sehingga menyebabkan tidak efektif pelaksanaan program ini. Hal ini dapat lihat dari banyak masyarakat yang menerima bantuan sosial tidak tepat sasaran.

Beberapa upaya yang dilakukan oleh tim koordinasi penanggulangan kemiskinan (TKPK) dalam mengsukseskan pelaksanaan kebijakan peraturan daerah tentang penanggulangan kemiskinan dan peningkatan kesejahteraan.

a) Dalam pelaksanaan kebijakan penanggulangan kemiskinan seharusnya menggunakan prosedur pendataan seharusnya berawal dari tingkat RT/RW sehingga masyarakat miskin lebih valid. Agar dalam pelaksanaan program penanggulanga kemiskinan setiap penerima bantuan sosial tepat sasaran.

b) Salah satu kunci utama suksesnya program adanya sumber daya. Upaya yang dilakukan adalah diharapkan kepada pemerintah agar lebih menambah dana untuk pelaksanaan peraturan daerah tersebut sehingga program tersebut dapat berjalan sesuai dengan apa yang diharapkan.

\section{Pembahasan}

Yesi Ermaini Simamora, Afriva Khaidir |38 


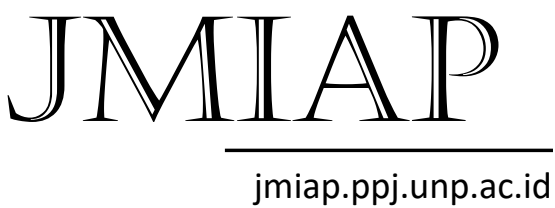

jmiap.ppj.unp.ac.id
Email : jianfis.unp@gmail.com

Vol. 1 No. 1 Tahun 2018
Berdasarkan hasil penelitian Implementasi Perda Kota Padang Nomor 2 Tahun 2013 tentang Penanggulangan Kemiskinan dan Peningkatan Kesejahteraan Oleh Dinas Sosial di Kecamatan Koto Tangah yang dilihat dari Model implementasi kebijakan publik yang digunakan oleh George C. Edward III dalam Dwiyanto (2009) menunjukkan empat variabel yang berperan penting dalam pencapaian keberhasilan implementasi kebijakan. Empat variabel tersebut: 1) Komunikasi, 2) Sumber daya, 3) Disposisi/Kecenderungan, 4) Struktur Organisasi.

a) Komunikasi

Komunikasi yaitu menujuk bahwa setiap kebijakan akan dapat dilaksanakan dengan baik jika terjadi komunikasi efektif antara pelaksana prohram (kebijakan) dengan para kelompok sasaran (target group). Pada Pelaksanaa Peraturan Daerah Nomor 2 Tahun 2013 Tentang Penanggulangan Kemiskinan dan Peningkatan Kesejahteraan di Kecamatan Koto Tangah oleh Dinas Sosial Kota Padang sudah dilakukan sosialisasi oleh tim koordinasi penanggulangan kemiskinan (TKPK) khususnya dinas sosial, tetapi masih banyak masyarakat miskin yang terdapat di kecamataan tersebut walaupun sudah banyaknya bantuan sosial yang sudah diberikan dan program penanggulangan kemiskinan yang telah dilakukan. Dan terkadang pemberian bantuan sosial tersebut tidak tepat sasaran, seharusnya pemerintah turun kelapangan melihat apakah bantuan tersebut tepat pada masyarakat atau tidak. Sehingga program penanggulangan kemiskinan tersebut dapat berjalan dengan baik dan tepat sasaran.

Hal tersebut tidak relevan dengan teori yang dikemukakan oleh Edward III dalam Dwinyato (2009:34) bahwa konseptual komunikasi ini siapakah implementor dan kelompok sasaran dari program/kebijakan. Dalam pelaksanaan kebijakan tidak berjalan dengan efektif oleh tim koordinasi penanggulangan kemiskinan (TKPK) khususnya Dinas Sosial. Seharusnya pemerintah dan Tim koordinasi penanggulangan kemiskinan (TKPK) khususnya Dinas Sosial selalu melakukan penyuluhan, pelatihan dan sosialisasi kepada masyarakat miskin agar masyarakat tersebut dapat mengubah perekonomian secara perlahan. Hal tersebut sesuai di ungkapkan oleh Dwinyanto (2009) bahwa metode yang digunakan sosialisasi adalah dengan pertemuanpertemuan melalui institusi yang telah ada, seperti Tim koordinasi penanggulanga kemiskinan, PKK, dan masyarakat. Komunikasi akan terjaga dengan adanya pertemuan rutin dan bekerjasama.

b) Sumber daya

Sumber daya yaitu menunjuk setiap kebijakan harus didukung oleh sumber daya yang memadai, baik sumber daya manusia maupun sumber daya financial. Pada Pelaksanaan Peraturan Daerah Nomor 2 Tahun 2013 Tentang Penanggulangan Kemiskinan dan Peningkatan Kesejahteraan di Kecamatan Koto Tangah Kota Padang dalam sumber daya manusia kurang memadai. Dan sumber daya finansial adalah kecukupan modal investasi atas sebuah program/kebijakan. Oleh karena itu, 
sumber daya financial sudah disediakan oleh pemerintah seperti APBN, APBD Provinsi dan Kota dan lembaga-lembaga no pemerintah. Sedangkan, sumber daya financial itu sangat menjamin keberlangsungan program/kebijakan pelaksanaan peraturan daerah tentang penanggulanag kemiskinan dan peningkatan kesejahteraan. Maka dari itu Peraturan Daerah Nomor 2 Tahun 2013 Tentang Penanggulangan Kemiskinan Dan Peningkatan Kesejahteraan oleh Dinas Sosial di Kecamatan Koto Tangah Kota Padang sudah berjalan tetapi belum memadai dalam mencapai tujuan dan sasaran. Kedua sumber daya tersebut sangat berkaitan dalam mewujudkan pelaksanaan program/kebijakan penanggulangan kemiskinan dan penanggulangan kesejahteraan oleh Dinas Sosial di Kecamatan Koto Tangah.

Hal di atas tidak relevan dengan teori yang dikemukakan oleh Edward III dalam Dwiyanto (2009) bahwa konseptual sumber daya dalam kemampuan implementornya sudah relevan yang mana kemampuan implementor adalah dilihat dari tingkat pendidikan, tingkat pemahaman terhadap tujuan dan sasaran serta aplikasi programnya. Tetapi dari hasil penelitian masih banyak terdapat masyarakat miskin di Kecamataan Koto Tangah, sedangkan dari ketersediaan dana belum memadai.

a) Disposisi

Disposisi, yaitu menunjuk karakteristik yang menempel serta kepada implementor program/kebijakan. Hal diatas relevan sesuai dengan teori yang dikemukakan oleh Edward III dalam Dwiyanto (2009) karakter pelaksana dalam tingkat komitmen dan kejujuran yang dapat diukur dengan tingkat konsistensi anatara pelaksana kegiatan dengan guideline yang telah ditetapkan. Semakin sesuai dengan guedeline semakin tinggi komitmennya. Tingkat demokratis juga dapat diukur dengan itensites pelaksana program kebijakanyang telah ditetapkan dan melakukan proses sharing dengan kelompok sasaran yaitu masyarakat miskin, mencari solusi dari masalah yang dihadapi dan melakukan diskresi yang berbeda dengan guideline guna mencapai tujuan dan sasaran program yang telah ditetapkan.

b) Struktur Birokrasi

Struktur birokrasi, yaitu menunjuk bahwa struktur birokrasi menjadi penting dalam implementasi kebijakan. Pada Pelaksanaan Peraturan Daerah Nomor 2 Tahun Tentang Penanggulangan Kemiskinan Dan Peningkatan Kesejahteraan di Kecamatan Koto Tangah Kota Padang struktur birokrasinya sudah ada dalam Permendagri Nomor 42 Tahun 2010 Tentang Tim Koordinasi Penanggulangan Kemiskinan Provinsi Dan Kabupaten/Kota dan tercantum dalam SK Walikota Nomor 146 Tahun 2018, dimana tim koordinasi penanggulangan kemiskinan (TKPK) itu merupaakan gabungan dari beberapa OPD bidang penanggulangan kemiskinan. Sedangkan untuk standar operasional procendur (SOP) disesuaikan dengan program yang dicanangkan oleh OPD masing-masing.

\section{Penutup}




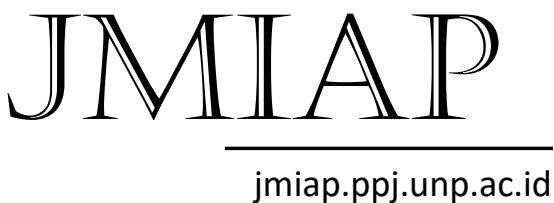

jmiap.ppj.unp.ac.id
Email : jianfis.unp@gmail.com

Vol. 1 No. 1 Tahun 2018
Dari hasil penelitian yang telah dibuat, maka penulis dapat mengambil beberapa kesimpulan yaitu:

1. Implementasi Perda Kota Padang Nomor 2 tahun 2013 Penanggulangan Kemiskinan dan Peningkatan Kesejahteraan oleh Dinas Sosial di Kecamatan Koto Tangah belum secara efektif dimana masih terdapat ketidaksesuaian penerima bantuan sosial yang tidak tepat sasaran, sebab sumber data tidak berasal dari daerah melainkan dari pusat. Selain itu sosialisasi hanya di berikan secara lisan serta sumber daya petugas kurang memadai.

2. Adapun faktor dari penghambat yaitu program penanggulangan yang dilakukan oleh Dinas Sosial dalam memberikan bantuan sosial kepada masyarakat miskin dengan menggunakan data basis terpadu dimana sistem top down yaitu keputusan masih berada dipusat sehingga menyebabkan tidak tepat sasaran bagi penerima bantuan sosial, anggaran dalam program penanggulangan kemiskinan tersebut kurang memadai dan masih banyaknya masyarakat mengaku masih berada dalam zona kemiskinan.

3. Implementasi penanggulangan kebijakan kemiskinan seharusnya menggunakan prosedur pendataan seharusnya berawal dari tingkat RT/RW sehingga masyarakat miskin lebih valid. Agar dalam pelaksanaan program penanggulangan kemiskinan setiap penerima bantuan sosial tepat sasaran

Berdasarkan kesimpulan penelitian, maka dikemukakan beberapa saran sebagai berikut:
1. Dalam sebuah perumusan kebijakan diperlukan sebuah alur yang panjang, sampai dengan sistem yang digunakan dalam sebuah pengambilan kebijakan. Dalam pengambilan kebijakan terbagi atas dua sistem yang sangat berkaitan erat dengan hasil dan dampak dari sebuah kebijakan tersebut. Dua sistem tersebut terdiri dari sistem top down dan sistem bottom up. Untuk penelitian ini, seharusnya dalam menentukan sumber data yang menerima bantuan sosial seharusnya dengan sistem bottom up, sehingga data yang diperoleh lebih valid dan lebih tepat sasaran dan mengetahui masyarakat yang layak dan tidak layak menerima bantuan sosial tersebut

2. Dalam mengimplementasikan sebuah kebijakan publik, terdapat beberapa tahap mulai dari perumusan kebijakan, implementasi kebijakan sampai dengan tahap evaluasi kebijakan. Tahap yang dapat melihat keberhasilan sebuah kebijakan adalah tahap evaluasi. Tahap evaluasi dilakukan dengan melihat dari keefektitasan sebuah kebijakan. Tahap evaluasi pada Implementasi Peraturan Daerah Nomor 2 Tahun 2013 Tentang Penanggulangan Kemiskinan dan Peningkatan Kesejahteraan Oleh Dinas Sosial, seharusnya dilakukan evaluasi dengan melihat langsung perubahan ke lapangan tingkat perekonomian masyarakat penerima bantuan sosial.

\section{DAFTAR KEPUSTAKAAN BUKU}

Anggara, Sahya. 2014. Kebijakan Publik. Bandung: Cv Pustaka Setia

Yesi Ermaini Simamora, Afriva Khaidir |41 


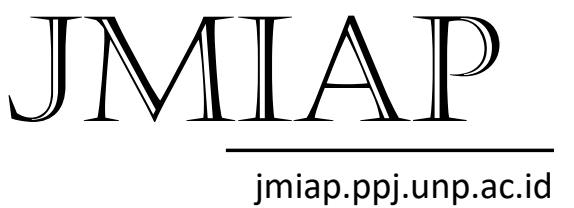

JURNAL ILMU ADMINISTRASI PUBLIK

Email : jianfis.unp@gmail.com

Vol. 1 No. 1 Tahun 2018
Herabudin. 2016. Studi Kebijakan Pemerintah dari Filosofi ke Implementasi. Bandung: $\mathrm{Cv}$ Pustaka Setia

Indihono, Dwiyanto. 2009. Kebijakan publik berbasis dynamic policy analysic. Yogyakarta: Gava Media

Moleong. Lexy J, 2013. Metodologi Penelitian Kualitatif Edisi Revisi. Bandung: PT Remaja Rosdakarya

Mulyono, Sungkowo Edy. 2017. Kemiskinan dan Pemberdayaan Masyarakat. Yogyakarta: Ombak Tiga

Setiadi, Elly M \& Kolip, Usman. 2011. Pengantar Sosiologi: Pemahaman Fakta dan Gejala Permasalahan Sosial: Teori, Aplikasi, dan Pemecahaanya. Jakarta: Kencana

Sjafari, Agus. 2014. Kemiskinan dan Pemberdayaan Kelompok. Yogyakarta: Graha Ilmu

Soerjono, Soekanto. 2010. Sosiologi

Suatu Pengantar. Jakarta: PT Raja

Grafindo

\section{JURNAL}

Yozi. 2010. Implementasi Program Penanggulangan Kemiskinan Perkotaan (P2KP) di Kecamatan Tonjong Kabupaten Brebes Tahun 2007. Fakultas Ekonomi Universitas Negeri Semarang. Volume 3. Nomor 1. HIm 64-74

\section{PERATURAN PERUNDANG}

\section{UNDANGAN}

Peraturan Daerah Kota Padang Nomor 2 Tahun $2013 \quad$ Tentang Penanggulangan Kemiskinan dan Peningkatan Kesejahteraan

Peraturan Walikota Padang Nomor 72 Tahun 2016 Tentang Kedudukan, Susunan Organisasi, Tugas, Fungsi, Dan Tata Kerja Dinas Sosial

Peraturan Menteri Dalam Negeri Nomor 42 Tahun 2010 Tentang Tim Koordinasi Penanggulangan Kemiskinan Provinsi Dan Kabupaten /Kota

Peraturan Presiden Nomor 15 Tahun 2010 Tentang Percepatan Penanggulangan Kemiskinan

Keputusan Walikota Padang Nomor 146 Tahun 2018 Tentang Tim Koordinasi Penanggulangan Kemiskinan

Undang-Undang Republik Indonesia Nomor 10 Tahun 2004 Tentang Pembentukan Peraturan Perundang-Undangan

Undang-Undang Republik Indonesia Nomor 32 Tahun 2004 Tentang Pemerintah Daerah

Undang-Undang Republik Indonesia Nomor 10 Tahun 1992 Tentang Perkembangan Kependudukan Dan Pembangunan Keluarga

Yesi Ermaini Simamora, Afriva Khaidir |42 


\section{JMIAP \\ jmiap.ppj.unp.ac.id}

JURNAL ILMU ADMINISTRASI PUBLIK

Email : jianfis.unp@gmail.com Vol. 1 No. 1 Tahun 2018
DOKUMEN

BPS. 2017. Profil Kemiskinan di Indonesia September 2016. Berita Resmi Statistik No 05/01/Th. Xx, 3 Januari 2017.

\section{WEBSITE}

Http://Padang.Go.Id

Https://Sumbar.Bps.Go.Id

Https://Padangkota.Bps.Go.Id 